\title{
MAGENDO: Arbitrage and Ambiguity on an East African Frontier
}

\author{
KEVIN P. DONOVAN \\ University of Edinburgh \\ (D) https:// orcid.org/0000-0002-3922-236X
}

Sometime in the mid-1970s, the proprietor of a shop at the Kenya-Uganda border town of Lwakhakha painted a new sign on his building: Mambo Bado. In the rolling hills below Mount Elgon, Lwakhakha is a relatively remote post, much less trafficked than Busia and Malaba to the south. At the time, the area lacked paved roads and electricity. Those few seeking waged labor or higher education had to migrate many hours away, to agricultural plantations or urban centers. Yet in a crucial way, the area was tightly integrated into extensive networks through smallholder cultivation of coffee. And it was this power of coffee to call forth and bring near exciting and exotic novelties to which this sign gestured: Things Are Still to Come.

In fact, things had already started coming to this frontier, and few residents had reason to believe it would cease anytime soon. Due to a spike in the world price and a surplus in Uganda, the area south of Mount Elgon became a massive transit zone for coffee. Price differentials between Uganda and Kenya made coffee trade an enormously profitable exercise. One village, in particular, became iconic. In a matter of years, Chepkube became a destination for fortune-seekers, the source of enormous wealth, and the subject of a popular song and a novel. For those in Chepkube and its environs, this trade, known by the Swahili word magendo, was 
filled with new opportunities, riches, and commodities. As the shop sign suggests, it opened the horizon for smallholders to imagine building novel, still undefined, futures for themselves and their families. The traders' frenzy brought forth new social practices as small-scale cultivators became commercial middlemen. Yet the revaluation of coffee did less to transform ideas about proper social relations and behavior, and the newfound permissiveness existed uneasily with inherited ideas about protocol and morality. As a result, by the time the trade ended a few years later, residents of this corner of Kenya were left with deep ambivalence about that which had come and gone.

This article examines the commercial techniques and moral ambiguities of magendo. I foreground the economic strategy of arbitrage, which has recently held the attention of anthropologists studying topics as varied as financial derivatives (Miyazaki 2013), assisted reproduction (Cooper and Waldby 2014), pharmaceuticals (K. Peterson 2014), and piracy (Dua 2019). In contrast to financial theory, which seeks a firm boundary between arbitrage and other styles of trading (e.g., speculation), in this anthropological literature, arbitrage is an ambiguous category and practice, liable to extension into new realms. It is also good to think with, "an interpretive framework that is widely deployable to various phenomena, economic and otherwise" (Miyazaki 2013, 36). I build on this work by arguing that arbitrage is not reducible to the simultaneous buying and selling of financial securities, nor the geographic movement between regulatory regimes as in the case of "labor arbitrage" (Ong 2006).

Instead, I conceive of arbitrage as the cultivation of difference. Frequently this occurs through the capitalization on price differentials between market jurisdictions, whereby regulations or norms in one place are evaded for those elsewhere (MacKenzie 2003). But this really constitutes only a subset of a broader practice of arbitrage, which Daniel Beunza and David Stark (2004) analyze in terms of exploiting "not only gaps across markets but also the overlaps among multiple evaluative principles." Magendo participants, I show, harnessed different calculative devices to produce price differentials, reminiscent of Jane Guyer's (2004) attention to the difference produced - including through "more or less deliberate interference" (Guyer 2016, 80) — by the translation between different currencies and commodities. In addition to spatial and calculative discrepancies, magendo margins could be produced by manipulating appearances, leading to manifest surfaces belying the quality of their underlying substance. Kristin Peterson (2014) has noted something similar in her discussion of "chemical arbitrage," with changes in drug composition at odds with their marketing; likewise, I show how coffee beans, weapons, and 
food entered an economy of (mis)representation through which deceit and fraud produced a new form of profit.

Magendo arbitrage, in other words, worked through the cultivation of and capitalization on the disjuncture of jurisdiction, measurement, and appearance. Residents of the borderlands experienced these practices as morally fraught, and I argue that arbitrage is particularly prone to generate social instability and ethical quandaries because its pursuit depends on a variety of shifts that cultivate difference. In other words, relatively stable assumptions and background conditions grounding social, economic, and political relations become matters of concern, liable to change, fluctuation, or even collapse. Putative equilibria are shown to be mere conventions, rather than matters of fact. The capacity to manipulate such evaluative schema, however, is not evenly distributed, with the result that the rewards of arbitrage often lead to an unsettling of received notions and mores about the appropriate acquisition and distribution of wealth. In these cases, it often becomes difficult to analytically separate arbitrage from speculation, let alone the resulting types of social discord and the moral opprobrium directed at it (Comaroff and Comaroff 2002; Miyazaki 2007). The assessments of this economic activity are rarely uniform; instead, arbitrage generates an ambiguous mix of desire and disdain. This article analyzes the culturally salient idioms through which moral ambiguity found expression and interpretation in a particular place and time. In doing so, it departs from the social studies of finance that tend to present socially attenuated worlds, with algorithms and infrastructures predominating. Instead, I emphasize the importance of the ritual practices and kinship idioms that facilitated magendo but that eventually strained under the eruption of newfound wealth.

In what follows, I focus predominantly on the Bukusu communities in and around Chepkube, and demonstrate that magendo dramatized tensions immanent to the area's population. Notions of moral selfhood, orientations toward others, and practical conceptualizations of time and space were thrown into relief, requiring participants to reason anew about how best to proceed in the context of extraordinary economic gains (Weiss 1996). This article analyzes the specific arbitrage techniques through which magendo unfolded before examining the ethical ambiguities that ensued. I detail the practical techniques through which differentials were actively created through the (re)working of jurisdiction, measurement, and appearance. These forms of arbitrage not only bequeathed a spectacular binge economy but also inverted the sociocultural categories that organized life. Magendo challenged prevailing ethics through its specific, material techniques and temporalities of arbitrage. In the narratives of residents who participated in it, 
magendo was characterized by the sudden proximity of once distant commodities, currency, and people; furthermore, domestic space gave way to the wild, and night became day. Such conceptual and experiential inversions not only heralded the danger of matter out of place but also ushered in previously foreclosed opportunities of wealth, respectability, and privilege. This twofold ambiguity — of peril and profit - formed part of a more general erosion of prevailing norms and forms of authority as magendo undermined existing ideas of propriety, respectability, and morality.

\section{ARBITRAGE AND THE CULTIVATION OF DIFFERENCE}

For residents of Chepkube, the magendo era during the second half of the 1970s still elicits considerable excitement. They recall it as a time when the fame of their small village spread across East Africa, even the world. Indeed, the village remains renowned for this period: I learned of it not long after beginning fieldwork along the Kenya-Uganda border in 2016. At the busy crossing of Busia, I spent my days with freight forwarders, the professional brokers who negotiated the paperwork and the people necessary to clear trucks through customs. These choke points were the objects of considerable technocratic intervention in those days, with newly constructed border posts meant to facilitate trade and taxation. Yet much of the trade continued to route around the new buildings, roads, and fences - including through the muddy paths of Sofia, the market and neighborhood where hundreds of traders daily bypassed the formalities of passports and customs. My inquiries into the types of work and wealth available at the border were often met by comparisons to the past, when the central states tended to invest less in the frontier, but also the moments when the border was reanimated, closed, or the site of frenetic, sometimes dangerous, activities.

A number of Busia's older residents invoked the period I analyze here. When one of the market women I knew offered to introduce me to her family in Chepkube, Kenya, I moved the couple of hours north to research this history. In time, my relations on the Uganda side deepened, allowing me to conduct parallel research on the history of magendo and its contemporary afterlives and manifestations. In addition to interviewing elders who participated in the 1970s trade, over the following months I shadowed politicians, police, and petty traders across the Malaba River and conducted archival research in collections on both sides of the border.

The period is remembered with a measure of amazement and a hint of nostalgia. Chepkube, I was told, "grew, and internationally it was known as a free 
market place, a black market." Residents of Chepkube mentioned the song and novel to me when trying to convey how remarkable the period was, but they also gestured around their homes, pointing to the durable property some managed to acquire from that period. Foremost in narratives of why Chepkube became such a renowned site was the presence of influential politicians from Kenya who used local buyers or their own kin when they "didn't want to be seen” at Chepkube. Chepkube, I was told, came to be known as "Nairobi B," a nickname whose overstatement served to mark the sense of extraordinary commercial standing from that time. No less notable was the arrival of outsider groups. "There were," my Ugandan host, Joseph, emphasized, “almost all tribes there.” A Kenyan teacher I know said similarly, "People came from everywhere-Kikuyu, Somali, even Kisii-and left money in Chepkube."

The boom in Chepkube also attracted new commodities. Merchants from Kitale and Bungoma brought clothes, pots, beer, whiskey, and more. Residents were flush with cash, leading tailors to sew special pockets into oversized jackets. Kikuyu and Somali buyers were particularly able to mobilize significant capital. "We could see people coming with bags full of money. . . . You could see someone walk in with a huuuuge handbag, carrying about 10 million shillings cash,” conveyed one man who traveled there to observe. I spoke to two brothers who started buying mattresses from Bungoma and selling them for a 50 percent markup in Chepkube. The Kenyan teacher, Victor, emphasized the novel opportunities: "Bicycles went up to Chepkube — brand new!"

The memorable period illustrated not merely the enduring opportunities of the frontier region but also its risks. To the extent that it was exceptional, it was of a degree rather than of a kind-illegal border trade remains commonplace. For this reason, the past remains present in Chepkube, not least as a morality tale about excess, accumulation, and labor. The lessons of such tales are not, however, straightforward, because, as I will discuss, much ambiguity surrounds magendo.

The source of this ambivalence is not the illegality of the trade, for state morality held little sway at Chepkube. In studies of smuggling, popular disregard for border controls emerges as a common observation, leading to a distinction between the "social perception" of trade as licit or illicit and its classification as legal or illegal (van Schendel and Abraham 2005, 18). This dichotomy, for instance, anchors Rebecca B. Galemba's (2012) analysis of how the officially illegal movement of corn across the Guatemala-Mexico border is nevertheless perceived and framed as licit by participants. The trouble with such an approach is that it gives popular perceptions meaning only in contrast to legal categories. Thus, despite aspirations 
to move "beyond state-centrism" (van Schendel 2005, 58), popular ethics hold interest only when mapped against state authority.

The experience of Chepkube suggests a different tack. Rather than its relationship to the law, magendo challenged people's ideas about the temporality of wealth, gendered and generational hierarchies, and the gap between surface and substance. In that way, it bears more resemblance to Filip de Boeck's (1998) analysis of the cross-border diamond trade in Zaire, where social critiques of accumulation and expenditure concerned not so much prohibited movement than the redirection of wealth toward socially sanctioned patterns of self-making and collectivity. Magendo's cultivation of difference-in terms of jurisdiction, but also measurement and appearance_— provided the basis for excessive proceeds, making wealth available in a manner "unsanctioned" by the prevailing social hierarchies of Bukusu society (cf. Roitman 2004, 79; Oka and Kuijt 2014).

\section{PANYA ROUTES THROUGH THE FOREST}

The source of Chepkube's newfound magnetism was, of course, the arrival of Ugandan coffee. The village was well placed geographically to serve as a transit zone for coffee, much of which had remained unsold between 1973 and 1978, when international embargoes on exports limited normal channels of trade from Idi Amin's Uganda (Asiimwe 2013). Instead, coffee poured out of seams in Uganda's territory, creating a hub of magendo on the eastern frontier. Ugandan newspapers exhorted citizens to stop the trade (D. Peterson and Taylor 2013), and security reports made frequent mention of magendo, despite an inability to document its true extent (e.g., Mbale District Archive 14/17; Jinja District Archive 13/17). In 1976 the Bugisu Cooperative Union (BCU) organized a series of meetings with its coffee-farming members, most of whom denied "that coffee was being smuggled" but raised a series of complaints revealing why such a trade would occur: delayed payments, low prices, and the unavailability of "essential commodities like sugar, soap, salt, etc" (BCU Archive, Minutes of the Committee Meeting, November 23, 1976). From the perspective of the provincial commissioner on the Kenya side, the following year was "an all-time high mark and such places as Lwakhakha, Chepkube, and Sio Port were household names in smuggling circles" (Kakamega Records Centre, HB/16/73). The matter even reached the records of the Central Bank of Kenya $(1978,5)$, albeit in the manner of an open secret, with the 1978 annual report noting "the record surplus in the balance of payments, and the highest ever accumulation of foreign exchange reserves" thanks to buoyant coffee exports. 
Successfully bringing coffee to Kenya required a careful negotiation of the landscape, often turning to areas previously unused, even proscribed. Bob Nakileza (2007) recalls "carrying heaps and heaps of [coffee] through the thick and dark forest, and the open alpine moorlands of Masaba mountain. . . . I toured the dark and open ecosystems of the mountain, [presumably] where my ancestors live." Participants from both sides of the border emphasize how far coffee came over steep mountain paths to reach Chepkube, up to a hundred kilometers on foot. "They would avoid towns, moving, and dodging, dodging." While bicycles or donkeys were available in some instances, Ugandan police patrols made the routes dangerous. The simpler the locomotion, the safer.

Roads were liable to interception, so arbitrageurs took to panya (rat) routes through the thick forests of Mount Elgon. Such routes required local knowledge that subverted the formalities of the border (cf. Weiss 1993, 23). Despite their use, Ugandans ferrying coffee through the frontier region were at risk because the Amin government opposed magendo. Ugandan soldiers and police plied the area, but so did civilian bandits pretending to be soldiers. "They would have gun-like tools," Joseph told me one day while walking across his fields, "and when they see people coming ... they go and take cover and they come up like they want to shoot them. So people throw their coffee and run away, and the [fake soldiers] collect their coffee and go and sell." The young men who perpetrated these thefts hoped to sell the coffee themselves. "These people, they were not using guns," but only pieces of wood designed to look like guns, so when they discovered the deceit, some traders attacked and killed the thieves.

Magendo thus relied on the successful manipulation of appearances. Arbitrageurs sought invisibility, while others misrepresented outward signs of authority. The skillful presentation of self also proved crucial if you were caught, because "it was your luck and how you are using your words when you meet soldiers." Others adopted a more aggressive dissimulation. Ugandan soldiers were hungry and poor, so intercepted travelers would feed them poisoned food. Others captured swarms of bees in a pot and released them if caught. Having covered themselves in paraffin, they could lie down and wait as the soldiers ran away.

Panya routes through the forest formed part of a more general reliance on undomesticated space. One Chepkube farmer noted his surprise at this abnormality: "Anyway, even people were sleeping in the forest! There were these people who used to use the forest routes. People went as far as waiting for coffee in the forest. There was even a market in the forest." The transposition of spaces of production and domesticity into the wilds of the forest was all the more unsettling 
because the forest represents danger, immorality, and secret knowledge. Forests, in the moral geography of my interlocutors on both sides of the border, constituted spaces unfit for habitation.

Yet Chepkube became a locus of magendo during this period precisely for its proximity to these relatively ungovernable areas. Though not without its dangers, the river crossing at Chepkube is relatively easy to ford. These geographic affordances allowed residents to insert themselves into the trade. While Ugandans found safety in Kenya - often rejoicing upon crossing the river - they could not remain for long. Even if they managed to pass as Kenyan by speaking Lubukusu or Kiswahili, Kenyan police would check for ID cards or a distinctive scar left by vaccination in their country. If caught, Ugandans would be deported. As a result, they were sometimes beholden to Kenyan intermediaries and could rarely partake for long in the forms of expenditure I discuss.

This impermanence allowed Kenyan frontier residents to mediate exchange between the brief visits of Ugandans and the bulk exporters of magendo coffee from Kenya. Incorporating locals facilitated the trade by drawing on the cultural infrastructure of the border. Locals could wait around for coffee arriving through panya routes that visitors would be unlikely to find. They could also speak to arriving Ugandans in their mutually intelligible languages, rather than Swahili or English (let alone Kikuyu or Somali), which would be less familiar.

\section{FRONTIER REPERTOIRES: Relatedness across Difference}

The populations demarcated as Kenyan or Ugandan in the region around Mount Elgon recognize a long, shared history. Peter Wafula Wekesa (2010) speaks of a "fluid cultural zone" on which the border has been imposed. The Bagisu of Uganda and the Babukusu of Kenya speak of a common history of origin, migration, and settlement. Their languages are mutually intelligible, and kinship networks often extend across the border. In both countries, they are known for their similar cultural practices, including the prominent biennial circumcision rituals. Yet it would be a mistake to overstate the unity of a population distributed across hills and valleys, which maintains pluralism, rather than a more muscular ethnic patriotism (MacArthur 2016).

Relatedness across difference characterizes frontier zones, providing latent repertoires of affinity (Nyamnjoh 2017). Frontier differences may be occasioned by an interstate border, but linguistic, economic, and other non-state dynamics may prove just as important (Kopytoff 1989). Mutually intelligible language, the assertion of ethnic and kin-based solidarities, and shared histories of coffee cultivation 
provided a repertoire on which the exceptional arbitrage economy could function in this region. Yet precisely because these repertoires facilitated exchange across disjuncture magendo proved so exceptional (Guyer 2004). Without the differential prices resulting from the distinct economic jurisdictions of Uganda and Kenya, arbitrage would not have occurred.

The existing ties across the border were formative for magendo. Consider the trajectory of Josiah. When my Ugandan host introduced me to his countryman, a farmer and trader, it was because of Josiah's reputation as one of the first to begin the magendo business. Josiah could do so because he was already working with a relative of his, a prominent man in Kitale, a town on the eastern edge of Mount Elgon in Kenya. In 1969, this relative asked him to surreptitiously bring Kenyan coffee to the Bugisu Cooperative Union in Uganda for sale, where the price was better.

In the middle of the 1970s, he reversed course, acquiring Ugandan beans for Kenyan buyers. As before, his circuit depended on a combination of kinship and connections to local notables. He set up shop on the Kenya side of the border with another relative and began moving coffee for sale to a Kenyan politician. He used a relative's home on the periphery of Chepkube to store coffee and opened a store in the market to sell soap, sugar, and other commodities.

Josiah was ambitious and, unlike many other locals, unsatisfied with being a middleman confined to Chepkube. He skipped the Kikuyu and Somalis coming to Chepkube and went up the commodity chain, directed by his existing contacts further afield. His ability to do so depended on having sufficient capital to acquire lorries. Also, in his opinion, Ugandans liked selling to a compatriot. Thus, Josiah did particularly well during magendo - eventually buying vehicles, land, and educating his children - because he was both closely embedded in the networks of kin and culture at the frontier and able to form more distant commercial relations. The relative paucity of people able to maneuver across such differences made his arbitrage lucrative.

Business was booming, and he recalls moving a hundred sacks of coffee per day, perhaps for up to KSh 3,000 per sack. His prominence did not go unnoticed, but when Amin sent "people in Kenya in the night to hijack him," he narrowly escaped. As he explained to me, his Kenyan colleagues helped him get back into business, with new capital and a portable safe to hide his proceeds. Fearful of returning to Uganda, he adopted the stance of an exile, and the Kenyan police, recognizing his importance to the trade, acquired an ID card for him "almost in a day." Josiah's story thus demonstrates how the ability to straddle different 
jurisdictions that remain apart, rather than homogenized, proved foundational to magendo arbitrage.

\section{MEASURE FOR MISMEASURE}

If the movement of coffee between territorial jurisdictions was the fundamental form of arbitrage during magendo, more subtle differences were cultivated and crossed by participants. These tactics sought to maneuver between distinct evaluative schema through which exchange was mediated and to manage relationships between the surface appearance and enduring quality of goods. As Guyer (2004) has influentially argued, the conversion between different techniques of measurement forms a critical part of African economic repertoires. Brad Weiss (2003, 169), too, has emphasized "the different strategic possibilities of measurement and quantification upon which the coffee trade depends." Magendo shed the state's enforced metrology, which determined price per kilo through marketing boards. At Chepkube, the translation between accounting by volume, by weight, and by Kenyan shillings offered skillful traders an opportunity to exploit additional magendo margins. This required perceptive cultivation and the management of difference, iterated over many individual transactions.

Ugandans arrived on the Kenyan side of the Malaba River with partially filled bags of coffee. These gunia - the iconic gunny sacks of the region-contained between ten and fifty kilograms of dried coffee. Local Kenyans, who had the luxury of time and identification documents, would be waiting to greet these sellers with something like the going price. Unlike in the official coffee purchases in Uganda, no central authority determined prices here. Those closest to the river might offer a slightly lower price, hoping the exhausted Ugandans would be happy to part with their coffee before traveling the final distance to Chepkube's market. Those that reached Chepkube's market would find a bustling scene with innumerable potential buyers. Their coffee was scooped from their half-filled bags and deposited in the buyer's gunny sacks. Each scoop was counted and Ugandans received payment accordingly.

The humble implement for scooping coffee was formative for magendo. Despite its simplicity, the gorogoro, as it is known, is a particularly noteworthy "market device” (Callon, Millo, and Muniesa 2007). A gorogoro, Kenyans will tell you, is a "two kilogram tin," most often repurposed from its original use as the container for popular store-bought cooking fats, such as Kimbo or Cowboy. At the time, cooking fats were one of the most common commodities purchased by rural households, and the sturdy containers in which they came provided a convenient 
afterlife. Like the commodity it once held, the gorogoro is standardized, providing a shared marketplace metric. In everyday speech, this standard is "two kilograms," a figure arising from the gorogoro's original label: " $2 \mathrm{~kg}$ of cooking fat." However, the commonality of an empty gorogoro is not weight; after all, the density of coffee (or whatever else is being measured) differs from that of cooking fat. Instead, the gorogoro offers a uniform standard of volume. Thus, while residents of Chepkube routinely referred to "two kilograms of coffee," as measured by the gorogoro, this was not a reference to weight, but rather to the standardized unit of volume provided by the empty cooking fat tin.

This presumed correspondence between weight and volume matters because the interplay between scales of measurement provided subtle forms of arbitrage. Scooping coffee out of arriving gunny sacks with a gorogoro standardized the variable amounts of beans brought from Uganda. As Ugandans were paid per gorogoro of dried beans, it also served as a tropic point (Guyer 2004, 49-50), commensurating a volumetric scale and a different unit of accounting, namely, Kenyan shillings. In the chain of magendo, the ability to enforce or evade such standardized commensuration - the construction of equivalence across difference - constituted tactics of arbitrage: the movement between fixed or variable relationships of weight, volume, and shillings were pivotal in the acquisition of marginal gains (Weiss 2003). Let me explain.

Magendo was characterized by one-off transactions. While some, like Josiah, built enduring commercial relationships, the vast majority of purchases occurred between individuals who did not know each other: "There was nothing like trust," explained a man who remembers shadowing his father in the trade. Traders took advantage of this fact through various means of inserting an additional margin on top of the prevailing price differences. Gorogoros, for example, not only measured coffee; they also detected impurities. Participants re-enacted for me how they would hold the full containers at eye level and pour the dried beans into their own gunny sacks, looking for rocks, sand, fruit, or other less valuable fillers.

Yet those coming from elsewhere in Kenya to purchase from Chepkube did not match the discerning caution of locals in this initial purchase. When they arrived from Nairobi with lorries, they did not measure in gorogoros; rather, they purchased gunny sacks by the dozens. Chepkube's residents, often with a laugh or a wry smile, explained to me some of the "funny, funny" tricks people would use, such as filling space with rocks. By the time buyers discovered such deception in Nairobi or Mombasa, it was hardly worth the time to follow up. 
In some cases, buyers took precautions. Over time, some gravity scalesfrom which a gunny sack could be hung and weighed - arrived in Chepkube, allowing buyers from elsewhere to pay per kilogram, rather than per gunny sack. Local arbitrageurs developed new tactics to produce a difference, most notably through soaking dried coffee beans in water over night "to bulk them." The plumper beans would then receive a cursory drying in the sun of only their exterior. In these cases, the density of coffee (and, to a lesser degree, its volume) again became a variable, as a surface-level dehydration could conceal the moistened coffee within. The presumed material fixity of coffee was transformed into a plasticity subject to manipulation. The aim of these scalar maneuvers was to insert (or detect) a small disjuncture between the worth of goods offered and the price received.

The introduction and maintenance of these forms of scalar variation would, eventually, be converted into currency. In the frontier zone, however, money took on particular characteristics. With the value of their currency plummeting, Ugandans faced a stark reality: even though they could receive a more valuable currency through magendo, Kenyan shillings lacked broad-based validity in their home country. The result was that magendo in Chepkube was conducted in Kenyan shillings. Scooped by the gorogoro, coffee was then priced in Kenyan shillings, with these notes quickly exchanged for commodities. For Ugandans, the Kenyan currency operated like a trade currency, incorporating them into temporary exchange with Kenyan coffee buyers and commodity sellers. It provided a technique of valuation, mediating between coffee and commodities, but it did not serve as an enduring store of value (cf. Maurer 2006, 20-21). Instead, Ugandans translated the arbitrage value of their coffee into manufactured goods that were portable and perduring.

\section{MAGENDO AND MORAL AMBIGUITY}

Throughout my fieldwork, laughter frequently accompanied stories of the excesses of the trade, subtly acknowledging the unequal opportunism. It served to hold together contradictions - namely that the attractiveness of unbridled margins existed alongside recognition that Ugandans received the short end of the exchange. Laughter represented a sort of admission, not so much of guilt as of immoderation, excess, and the ethical ambiguity surrounding them (cf. Yeh 2017). The moral ambivalence around magendo did not arise from the illegality of the trade. Cross-border exchange was a long-standing practice for residents of this East African frontier, and the territorialization of economies exerted a weak force on their ideas about legitimate commerce. 
Instead, the disquiet of the period resulted from a transformation in the accessibility of wealth and, in turn, the erosion of forms of authority and behavior that ordered ethical life. In other words, it was not the state's morality that provided a "moral metalanguage" (Keane 2008) to magendo but rather concerns about the proper timing and socialization of wealth (De Boeck 1998; Dua 2019). The cultivation of and capitalization on disjunctures of jurisdiction, measurement, and appearance was widely pursued, yet the resulting wealth from this arbitrage challenged the social norms and conceptual schema of frontier residents. The rest of this article examines the implications of this phenomenon. An undisciplined "binge economy" replaced the perceived orderly arrangement between men and women, seniors and juniors, production and consumption. A sense that generational and gendered expectations and hierarchies were dissolving accompanied the inversion of conceptual and perceptual schema. Three particular inversions arose throughout my conversations with residents: what was once distant became local as space was compressed; anticipated temporalities vanished in the frenzy of trade; and distinctions between the productive and domestic spheres and their ungoverned, wild complements dissolved. The following sections analyze these in more depth. The idioms and tropes through which my interlocutors expressed these ideas reveal a sense of peril regarding the magendo era, but such unease never veered far from its cause: the enthusiastic embrace of magendo's opportunities. Thus, memories of the period remain ambiguous, with contradictions often held together by ironic laughter.

\section{BINGE ECONOMY: Money and People out of Time}

While Ugandans returned home with the commodities of social reproduction, Kenyans turned their spending toward consumption. Binge economies can occur for many reasons - the discovery of new exports, say, or speculative frenzies - but around Mount Elgon, it was arbitrage that formed the basis for the dramatic accrual and dissipation of wealth. Arbitrage also allowed participants to capture and redirect value in unprecedented ways. In Richard Wilk's (2014) conceptualization, binge economies are typical of extractive frontiers "on the margins of the capitalist world system.” They are marked by excessive, seemingly irrational, expenditure where what counts is less the stability of one's pocketbook than one's ability to spend as quickly as possible. Such performances of one's detachment from money demonstrate one's daring and joie de vivre. In Chepkube, too, competitive gift-giving emerged as a common form of conviviality: 
People were very generous! A lot of drinking. Bars opened from nowhere. They would say, OK, I have a lot of money, I want to buy you a beer; you are my friend. Stand up! You stand up. I would pile crates of beer-Tusker, Pilsner — up to your height, and that's yours!

Where previously only locally brewed alcohol was available, now brand-name beer and even whiskey arrived from distant factories. Chepkube's market used to operate only one day a week, with a single bull slaughtered for sale, but during this period, upward of ten heads of cattle were butchered, and "by 10 p.m., there was no meat left!"

Participants remembered such consumptive possibilities with relish, but they also manifest an unsettled order of age, gender, and rank. Throughout East Africa, alcohol and meat are symbolically charged goods (Willis 2002). Bukusu men historically demonstrated their worth through the quality of their homebrewed beer and their generosity in its distribution. Only elderly men (and sometimes women) could enjoy beer drinking as a regular pastime; younger folks only enjoyed it at special events or as a reward for labor (Wagner 1956, 68-74). These restrictions on consumption - and attempts to subvert them - are constitutive of the contested claims to authority of senior men. Notions and practices of drinking are, therefore, practical enactments of hierarchical and exclusive social relations; transformations in access-due to commodification, regulation, or economic change - can unsettle norms of respect and power. In the case of magendo, such new consumptive possibilities formed part of a more general disordering of people's relations, wealth, and temporalities.

Binge economies are characterized by their presentism, but unlike the "evacuation of the near future" traced by Guyer (2016), this presentism in the Kenya-Uganda frontier was not matched by austerity and pecuniary lack. Instead, it was the immediacy with which wealth was available that militated against all other activities. There was no time to spare. Big buyers coming from afar would rent hotel rooms in the closest urban centers of Bungoma or further south. Others "just broke some branches [for] a makeshift camp" and "slept in the bushes to buy the coffee." Such arrangements belied the weight Bukusu communities have historically given to a proper home, seeing deficient housing as a sign of indolence (Wagner 1956, 2). Yet during the coffee boom, such basic concerns received little attention. Walking one day near the river that divides Uganda and Kenya, my friend stopped and pointed: "It was like a refugee camp here." Government ministers and their wives - even Margaret Kenyatta, I was assured — turned to such 
rudimentary quarters. Naively assuming the former mayor of Nairobi and daughter of the country's founding president could afford it, I asked, why not have a house built here? The answer was immediate and followed by hearty laughter at the incongruous, even carnivalesque, logic of the time: "Who's going to build? Where are you going to get the labor?"

The velocity of money also accelerated (cf. Parry and Bloch 1989, 24-30). Some big buyers received substantial advances from banks, permitting them to turn a larger profit. If you were a well-connected Kenyan, “overnight, you came and got 10 million shillings [in cash from the bank], you go and buy, take it, and by the time you reach Nairobi, or before, someone is buying it to take it to Mombasa. You pay it [the loan] back and go back again.” Such stories illustrate the rapidity and repetition with which buyers scrambled for access to cash to buy arriving coffee. I was told of a senior government official and confidant of the president whose wife spent time in Chepkube. The minister "used his position" to get all the cash from the main bank branch in Bungoma. "People needed cash to buy coffee at Chepkube, so the bank even ran out of cash, failing to pay teachers because of it." The Nairobi headquarters had to airlift cash to ameliorate the shortage. Others turned to cooperative agricultural societies, using their collectively held cash as an advance to purchase magendo coffee. In both these stories, collective futures (of children's education and farmer cooperation) were mortgaged for immediate gains.

Residents of Chepkube experienced magendo as repeated, one-off transactions. As such, cash was the most appropriate money form.

"Did anyone at Chepkube buy coffee on credit?" I asked.

"No, it was magendo, so something like credit was not appreciated, because you don't know that person from Uganda. It was cash! There was nothing like trust."

The financial techniques through which trust is mobilized, secured, and extended across time and space (such as the provision of credit on the promise of future repayment) did not find a place in the magendo economy. The accounting books and receipts that would provide traces of such transactions were unnecessary not because of the trade's illegality but for the lack of its orientation to the future (McGovern 2018).

Moralizing observers often condemn a lack of orientation toward the future, the inability to do anything but "live for the moment" (Day, Papataxiarchis, and Stewart 1999). Many residents of Chepkube offer a similar reflection on the period. Amid the dramatic consumption, few invested in productive assets. "People were busy," one former teacher told me. "Even our own coffee farms could not 
be managed. Because people were interested in getting easy money, quick money, only a few managed their farms." While few at the time resisted the attraction of magendo's immediacy, with the benefit of hindsight, some see "easy money" as a significant mistake (cf. Shipton 1989; Znoj 1998; Walsh 2003; Weiss 2003, 101-2). The "people who were getting money in an easy way," others told me, "it has ruined their lives. Because they have now had to learn to struggle for their lives by farming [or] doing businesses." In their reckoning, meaningful value was durable, and it took time and sweat to accumulate (cf. Heald 1989). Only over time was it possible to gain the value that came about through the experience and productivity of discipline; this required converting quicker money into more enduring forms of value, such as land (Kusimba 2018). Wealth out of time - that is, money realized without the normal perquisites of self-restraint and collective effort — was likely to run out in no time.

The exigencies that characterized magendo upended existing temporal rhythms. Instead of the year being marked by discrete periods of coffee harvesting and marketing, the calendar was now completely dominated by coffee trade. The buildup of coffee supplies in Uganda meant arrivals throughout the entire year. Moreover, Chepkube's weekly schedule was usually punctuated by a single market day. Yet during magendo, "there was no market day." Instead, it was "every day. Morning. Night. It was full!” The pursuit of profit began to override domestic time. Magendo proved a twenty-four-hour, seven-days-a-week affair. "Every hour people were operating; night and day were just the same." Because Ugandans could best elude their country's soldiers at night, much of the business was conducted after the sun set. Despite the night, the Kenyan side was illuminated; there was no electricity in the area, but paraffin pressure lamps were common. "When you come from very far, you find this place was very clear, like daylight! And the business was working day and night, not stopping! No sleeping!”

The productivity of the night still animates residents. One elderly gentleman exclaimed "Chepkube used to be like Cabinda in Angola_-during even night, lights!" A friend sitting quietly until this point chimed in, "like Dubai, with people buying. That is how Chepkube looked." In both cases, the references to petro-state profligacy - the flares of Cabinda's rigs and the ostentatious glare of Dubai's malls - seemed the best parallel for the transformation of their village. "People were not feeling any exhaustion at all," I was assured, because they were making profit. "He went about all day and night and tomorrow you will see him still on the same business." The rewiring of biorhythms, the fueling of superhuman energy — such was the sense of the time. 


\section{ARBITRAGING GENDER AND GENERATION}

The trade attracted women, too. Concerned men told me of "reckless women [who] abandoned their responsibilities" to the household. "Even women, they were not staying in their homes. They had also become another problem," laughed one man suggestively. "As their husbands went, they also went. Perhaps they also came home late, just to sleep. The next morning, they had gone to look for moneybecause everyone was chasing money!" Women brewed beer and cooked meat for the crowds, both potentially suspect activities marked by masculine sociality and indulgence.

This concern reflects a more general anxiety of the time about the proper source of authority. For Bukusu communities, proper standing as an adult — with its rights and duties _ does not emerge in a single moment but rather from an extended performance of rectitude. Moreover, it requires the formation and maintenance of suitable relations with others. Rites of initiation-preeminently male circumcision, marriage, and childbirth — create particularly intensive opportunities to demonstrate character and also make evident networks of mutual obligation and entrustment (la Fontaine 1977). These rites, ideas, and arrangements secure a particular distribution of resources and regard, and are shaped by ideas about the proper timing and sources of accumulation.

In the communities around Mount Elgon, patriarchal gerontocracy oriented productive activity and domestic life. As Wagner $(1949,77)$ asserted based on research between 1934 and 1938, "the authority of seniors over their juniors, the principle of seniority, prevails in all social relations." Yet the manners in which these arrangements apportion and control access to wealth and respectability are not without their limits and tensions. Suzette Heald's (1989) work on the Ugandan side of the border emphasized the countervailing pressure from the "aggressive individualism" cultivated in young men who endeavor to "win economic independence from [their] father[s]." This leads to a "strong pattern of intergenerational conflict" (Heald 1999, 77) in which the transmission of property is eminently important. Sibel Kusimba's $(2018,3)$ recent study of Bukusu rites similarly notes this tension, with elders "endors[ing] the importance of long-term and often collective investments, assets, and inheritances," such as land, compared to others who may prioritize "short-term moneys." Such discontent often coalesces around the timing of initiation, where sons receive a part of their inheritance, despite the father being relatively young himself at that time. It is common for boys in the area to pester their fathers to be initiated, with the fathers demurring in part to delay providing the land and cattle necessary for their sons' autonomy. Increased 
land scarcity in the twentieth century only exacerbated the tension. Importantly, the object of frustration here is the patriarch — not the patriarchy. The antagonism reveals, in other words, a mutual investment in seniority, despite the limited resources through which to achieve proper adulthood.

It is in this context that magendo wealth is significant. Prima facie, the resources available through magendo offered a means to accumulation that avoided competition between generations. Magendo during this period provided a means to economic advancement that did not come at the cost of one's father, explaining the permissiveness that greeted it. Yet the shared schema and expectations about wealth were, eventually, thrown into relief and challenged during the binge economy. Not least, this occurred because of the quickening of the extended schedules through which life courses historically unfolded, as well as the narrowing of the relations necessary to uphold them.

As an example, the regulatory function of marriage - through which individuals enter into a more senior, mature role and through which property becomes redistributed across generations and families — was tested by arbitrage wealth. As Peter, my host's neighbor, put it, magendo "was spoiling people, particularly the younger generation. Marriage was a problem. Someone could marry five wives because he has money, [yet] he couldn't support all of them" after magendo ended. Ritual time accelerated, and with it the stature achieved through maturity was debased. Whereas the sequencing of marriage, including the transfer of thirteen cattle, was typically drawn out over a longer period, newly enriched men could skip such time. The performance of ongoing entrustment signaled by the non-repayment of debt was cut short, suggesting impertinence (Shipton 2007). "Even some [of my age mates] got married when they were very young, because they were thinking, it was their only chance to get married," said one man who was initiated in 1978.

In these cases, it was not so much that ideals had changed-marriage was still the goal, after all_-but rather that the proper temporalization had eroded. Some marriages fell apart, only to be reconstituted otherwise: "During magendo, it was easy for someone to leave his wife, or to leave her husband because when they come here, from Mbale there in Uganda, and another one comes from Kakamega, they meet here, [and] that one from Mbale will leave her husband and go with this man from Kakamega. Marriage was very simple." Such a temporal acceleration is usually considered the domain of the capitalist core, as Laura Bear's (2016) discussion of the "extensions of short-term market time" and "intensifications of capitalist time" demonstrates. Yet the arbitrage wealth during magendo 
shows a similar dynamic of accumulation and acceleration far from capital-intensive infrastructure or the logics of financialization. For the frontier residents I know, it is through the idioms and examples of kinship and initiation that such dynamics find expression.

In addition to the perceived impatience of young men and the imprudence of women, another index of gerontocratic impotence figures prominently in memories of the time: even children became involved in the trade. Children stopped attending school to collect fallen coffee beans in the market. "A boy, a girl, sometimes twelve years, ten years, sometimes maybe eight years, even as young as six, seven," Victor, the teacher, told me, "So the little girl or little boy would pick and put them in a two-kilo tin of Kimbo, cooking fat, fill it, and when it is full say, 'Sir, can you buy it?' They bargained, 'OK, I'll give you twenty [or] I'll give you ten.' That was a lot of money; for sugar, a kilo might have been three shillings at that time."

Magendo invited children into the disposition of their seniors, bargaining as any other adult would (cf. Meiu 2017). Pupils stopped attending school, explained an elderly teacher, because "discipline and hierarchy collapsed. Both teacher and student engaged in the same business, so in this sense they were equal." One man mimicked the act of bending over and picking up individual coffee cherries spilled on the ground: "So, even little children, of standard 3 or standard 4, had money in their pockets!" With their money, they could acquire material trappings beyond their age. "They even bought new shoes!" exclaimed one man who remained scandalized by the memory of typically barefooted children donning footwear.

Some schools stood empty, with neither teachers nor students bothering to attend. The economic logic seemed clear: teachers may have been paid 4,000 shillings a month, one man recalled, but in magendo you could get 20,000 in a day; even 10,000 in a couple hours. In the exuberance of magendo, protracted avenues for the production of valuable futures - waged labor and education - were traded for the immediacy of arbitrage. Some were worried: as schools emptied, an illiterate generation loomed. But as paternal authority waned, little could be done against the allure of arbitrage. "It got us worried. We had to complain. But even if you complained, what would you do? The child leaves you and goes to look for this business."

Senior men found the situation disconcerting, even existentially threatening. "There was no respect because everyone was rich by that time," said one former subchief. 
"For elders! If you now have a child having, I mean, more than, let me say, 100,000. And you have no money [as an elder], he overlooks you! What do you do for him? He can even buy you.” The broad accessibility of the trade and its resulting wealth undermined the hierarchies through which juniors and seniors related, value was apportioned, and moral values practiced. In the views of senior men, uncontrolled access to money permitted their social juniors to bypass not only proper authority but also the patient cultivation of responsibility. ${ }^{1}$

\section{ECONOMIES OF MISREPRESENTATION}

I have suggested that the management of appearance was a central concern during magendo, but over time a wider economy of misrepresentation took hold. Representations during magendo often misled, whether through the peeling apart of surface appearance and underlying substance, or the case of the Kenyan government elite managing their (non-participatory) image while still partaking. ${ }^{2}$

These forms of deceit did not always rankle participants' moral intuition: as studies of fake goods make clear, "everyday dissimulation [is] a social modality" (Newell 2019, 300) not merely defined by resentment and objection (Guyer 2004, 86-91). During magendo, opacity, deception, and pretext were often negotiated, rather than uniformly rejected.

Yet not all magendo duplicity met with ambiguous laughter, and over time some acts did provoke indignation and condemnation. For example, dishonest butchers sold meat unfit for consumption. "There was a time when there were very many dogs," a Chepkube farmer told me. "Then, all of a sudden: there was not a single dog!" Unscrupulous vendors, he thought, "were selling dogs at night, maybe from midnight when there was no more meat, to 2 a.m." Another confirmed this rumor, emphasizing that the timing of magendo proved central to the impropriety: "That one happened, because as I said, people used to do this business at night, then at night people could do anything." No matter how illuminated, the night was a time of risk and danger. He continued, pointing to the intrusion of undomesticated spaces and their products into domestic consumption: "Yes, we had people from the forest who could come with elephant meat, perhaps antelope meat. At night, people could eat anything. You had to be very careful to not eat things at night. But they were sold mostly to those who came at night to buy, because they were tired, hungry, and they could land on certain meat." Inoculating oneself against these dangers, he suggested, was particularly difficult for new arrivals that lacked the careful disposition Chepkube demanded in those days. 


\section{MAMBO KWISHA}

The most dramatic incident of the magendo era-indeed, its denouement in the view of some - arose from the realization that some people used counterfeit Kenyan shillings to buy coffee. Chepkube's residents were on the front line of buying coffee from Ugandans and selling it to Kikuyu and Somali bulk buyers. The difference between the price in Chepkube and the price offered by international buyers in Mombasa was enormous. It compelled a scramble between Kikuyu and Somali buyers to acquire as much coffee at the frontier as possible. It also compelled some unscrupulous buyers to bring counterfeit money to Chepkube, slipped into bundles of genuine currency — an act uniformly blamed on Somalis. With such free money, these individuals could afford to outbid their competitors.

The same quality that made cash attractive - its immediacy and lack of records - made recuperation unlikely. This angered participants, not least because it cut them off from the consumptive networks into which they had so eagerly entered. Some experienced it as a return to poverty. In fact, many blame the fraud for the ultimate end of the binge economy. When word went out that the Somalis had been defrauding the sellers, "the Kikuyus complained and started beating the Somalis." The incident — with the attackers armed with pangas, spears, stones, and other implements - turned into a daylong conflagration, with other participants joining the assault. Those present remember the day well. "It was a very big confusion. People died." Kenyan police did not arrive for hours. Instead of keeping the peace in busy Chepkube, they were under orders to remain at their post in distant Malakisi. In the meantime, perhaps as many as seven or eight people died, mostly Somalis.

In the absence of police, the very same gerontocratic authority sidelined by magendo restored order. "The center of all the fighting was here," I was told as we sat drinking soda overlooking the border river, "at this junction. I remember two people who tried to stop the fighting: my late father and the late R. M. These ones carried spears, and held up spears." My friend adopted a look of stoic resolve and mimicked the act of holding a spear above his head, pointing straight up. "They were not scared of the stones being thrown in the middle. And it was stopped. So when the police came, everything was in control." His age-mate, sitting near us, chimed in, explaining that these men were highly respected elders: "They were the ones who kept the peace." The police, failing to find anyone willing to testify, returned to their base and let the elders' solution suffice.

For others, it was not counterfeit money and the enfeebled local gerontocracy that ended magendo. Rather, it took the paternal authority of "the elder state" 
(Ocobock 2017) to bring arbitrage to heel: some residents of Chepkube recall the death of Jomo Kenyatta and Daniel arap Moi's assumption of power as the change that ended the trade. "If Kenyatta could [still] be on the throne," said one former subchief, "I think things would continue because his own family were the ones here, they were having trucks here, buying." Nationally, Kenyatta and his family are remembered as acquisitive, even indulgent. This permissiveness is subtly contrasted with Moi, a well-known teetotaler and churchgoer, not tempted by earthly pleasures (Lynch 2011). By the time he was forced aside in 2002 after twenty-four years in power, Moi had solidified a reputation for authoritarian control that was presaged, frontier residents suggest, in his closure of arbitrage. My interlocutors juxtaposed Moi's rectitude in moral matters with the ethical ambiguities of magendo; the austerity of this famous arbiter of order stands against the exuberance of the period. His rule, in their eyes, curtailed the drunkenness, school-leaving, and disrespect for elders associated with magendo.

Only with the change of power in Nairobi did a new provincial commissioner, a born-again Christian from the coast, I was told, arrive in western Kenya. This man went to Lwakhakha, the small border post south of Chepkube, and found the iconic shop sign declaring Mambo Bado — things are yet to come. Ordering his officials to bring paint and rub off those optimistic words, he scrawled a new slogan, Mambo Kwisha - things are finished! In this symbolic act, he concretized the closure of magendo, declaring an end to its open orientation to the future and consigning its extraordinary dynamics to the past.

\section{CONCLUSION}

Seen from the perspective of Wall Street's high-tech offices and high-speed algorithms, arbitrage can seem an exceptional economic strategy. Available only to the heavily capitalized, it is exclusive and distinct from wider cultural and political entanglements. Indeed, even the language of "high finance" gestures to its removal from the mundane, worldly concerns of other sorts of commerce. Yet this article has demonstrated that capitalization on differences between market jurisdictions is not uniquely the preserve of financiers. It has examined such spatial techniques alongside related ways of creating differences through the manipulation of measurement and appearance. This wider view of arbitrage demonstrates the sorts of cultural infrastructure required to transact across differences - cultural norms and social relations occluded in corporate offices.

Seen from the perspective of Chepkube, arbitrage is a style of action suited to frontiers where relatedness across difference has long been valued. Here, it is not 
so much incorporation and homogenization that define social relations and commerce. The experience is not one of a "great transformation" (Maurer 2006) resulting in commensuration and abstraction. Rather, virtue abides in simultaneously holding apart and moving between registers. This sensibility, I have argued, made the people around Mount Elgon well suited to the period under discussion. The "messiness and hard work involved in making, translating suturing, converting, and linking" across heterogeneity was not an intermediary status to be overcome (Bear et al. 2015). Rather, the variegated field of action — knowing and measuring, presenting and obscuring, moving and enclosing — concerned both the means and the ends of arbitrage.

Such an approach suggests that despite its association with movement, arbitrage sits in place. We might say it is nestled alongside kinship, ritual, and ethics - the sorts of domestic concerns shorn from other studies of arbitrage. Shared rites, common vernaculars, and histories of intermarriage provided the basis for magendo, yet they also strained under the exuberant embrace of its rewards. The ethics, temporalities, and hierarchies of Chepkube's gerontocratic order saw their material bases erode: wealth became accessible without laborious production, marriages could occur without extensive contributions from kin, and social juniors could partake in typically senior behavior. Arbitrage appears particularly prone to generate such conundrums, for when it is pursued widely, it relies on a subversion of the orderly arrangement of people, timelines, appearances, and standards.

Magendo dramatized such an erosion of prevailing norms by expanding commodity consumption, accelerating rites of initiation, and undermining elder claims to wealth and prestige. These dramas demonstrate that arbitrage is more of a political phenomenon than often recognized - especially if the political is understood beyond state sovereignty to include the regulation of the life course, the inheritance of land, and the consumption of prestigious goods. Arbitrage is a challenge to settled orders of status and wealth. In this way, it might seem akin to the sorts of hostilities associated with millennial capitalism (Comaroff and Comaroff 2002), though the comparison only goes so far. In contrast to the assumptions about zero-sum rivalry and competitive displacements, magendo invited all to partake in the resources and statuses historically reserved for the few. The excess rewards and conviviality formed part of the more troubling inversions of conceptual schema and the decline in ethical behavior. Arbitrage, in other words, provides simultaneous peril and profit that are best captured in the lasting motif of the era: an ambiguous laugh. 


\section{ABSTRACT}

This article examines the ambiguities of arbitrage, focusing on illegal coffee trade across the Uganda-Kenya border. I show how residents of the borderlands harnessed ordinary tools (gunny sacks, tin cans, and gravity scales) and cultural repertoires (kinship, language, and ritual) to cultivate and capitalize on difference. They reworked territorial jurisdiction, measurement standards, and surface appearances in a form of arbitrage known as magendo. While magendo is an ordinary occurrence at the border, I focus on a particular period in which magendo reached spectacular new levels. The resulting binge economy was characterized by competitive gift-giving and interethnic conviviality, but its excessive margins eventually challenged prevailing notions of moral selfhood, gender relations, and the authority of elder men. Seeing arbitrage not merely as the reserve of high finance but also as a strategy of African frontiers provides a way to connect the anthropology of finance to enduring concerns around the postcolonial politics of borders, gerontocracy, and value. [arbitrage; smuggling; East Africa; temporality; money; borders]

\section{MUHTASARI}

Nakala hii inachunguza utata wa arbitrage. Maandishi yangu yanazingatia biashara wa kahawa mpakani mwa Kenya na Uganda. Katika nakala hii, ninaonyesha jinsi wakazi wa mipakani walitumia zana za kila siku (magunia, madebe, na mizani) na pia mbinu za kitamaduni (ukoo, lugha, na mila) kuzalisha na kukuza tofauti za kisokoni na faida. Aidha wahusika hawa walipinda na kufinyanga dhana kuhusu udhibiti wa mipaka, desturi za kukadiri, na muonekano wa nje kwa kupitia kitendo cha arbitrage: almaarufu kama magendo. Ingawa uchukuzi magendo si taratibu geni kwa uchumi za mipakani, nakala hii inazingatia wakati ambapo uchuuzi wa kahawa ulifikia kilele cha kustaajabisha na kuleta uchumi wa ukwasi. Kwa upande moja msimu huo ulileta urafiki kati ya jamii tofauti na mienendo kama vile mashindano ya kutunukiana zawadi. Kwa upande mwingine, faida za kiajabu ziliibua miangalio mipya kuhusu maswala ya uadilifubinafsi, jinsia katika jamii, na mamlaka ya wazee. Kuelewa arbitrage kama zaidi ya mazoezi ya kifedha, bali pia kama mkakati wa uchumi za mapembezoni, inatupa njia ya kuunganisha anthropolojia ya fedha na masawali ya mipaka baada ya ukoloni, utawala wa wakongwe, na thamani. [magendo; fedha; Afrika Mashariki; mipaka; ulanguzi]

\section{NOTES}

Acknowledgments I am grateful to conversations on these topics with Godfrey Asiimwe, Amiel Bize, Emily Brownell, Jatin Dua, Basil Ibrahim, Emma Park, Parker Shipton, and Peter Wafula Wekesa. Brad Weiss and the $C A$ reviewers provided valuable guidance, and Jessica Lockrem helpfully managed it all. My thanks to all.

1. It was not uncommon that residents born after this period knew the dynamics, its opportunities, and its missteps. Indeed, memories of that time serve as something of morality plays, inculcating a respect for those ideas, principles, and dispositions debased 
during the magendo boom - even while few would deny the allure that such immediate riches would undoubtedly present if they arrived again.

2. There is an echo of Andrew Apter's (2005, 283; cf. Mbembe 2001; Blunt 2019) argument about a postcolonial condition of "semiotic suspension, in which signs, stripped of their referential moorings, are almost literally up for grabs." But in contrast to Apter's view of a generalized epistemological rupture, the case here points to specific registers in which socially salient inversions were experienced (e.g., night and day, domestic and wild).

\section{REFERENCES}

Apter, Andrew

2005 The Pan-African Nation: Oil and the Spectacle of Culture in Nigeria. Chicago: University of Chicago Press.

Asiimwe, Godfrey B.

2013 "From Monopoly Marketing to Coffee Magendo: Responses to Policy Recklessness and Extraction in Uganda, 1971-79." Journal of Eastern African Studies 7, no. 1: 104-24. https://doi.org/10.1080/17531055.2012.755312.

Bear, Laura

2016 “Time as Technique." Annual Review of Anthropology 45: 487-502. https://doi. org/10.1146/annurev-anthro-102313-030159.

Bear, Laura, Karen Ho, Anna Tsing, and Sylvia Yanagisako

2015 "Gens: A Feminist Manifesto for the Study of Capitalism." Theorizing the Contemporary, Fieldsights, March 30. https://culanth.org/fieldsights/gens-afeminist-manifesto-for-the-study-of-capitalism.

Beunza, Daniel, and David Stark

2004 "Tools of the Trade: The Socio-Technology of Arbitrage in a Wall Street Trading Room." Industrial and Corporate Change 13, no. 2: 369-400. https://doi.

Blunt, Robert W. org/10.1093/icc/dth015.

2019 For Money and Elders: Ritual, Sovereignty, and the Sacred in Kenya. Chicago: University of Chicago Press.

Callon, Michel, Yuval Millo, and Fabian Muniesa, eds.

2007 Market Devices. Malden, Mass.: Blackwell.

Central Bank of Kenya

1978 Twelfth Annual Report for the Financial Year Ended 30 June 1978. Nairobi: Government of Kenya.

Comaroff, Jean, and John L. Comaroff

2002 "Alien-Nation: Zombies, Immigrants, and Millennial Capitalism." South Atlantic Quarterly 101, no. 4: 779-805. https://doi.org/10.1215/00382876-101-4-779.

Cooper, Melinda, and Catherine Waldby

2014 Clinical Labor: Tissue Donors and Research Subjects in the Global Bioeconomy. Durham, N.C.: Duke University Press.

Day, Sophie, Evthymios Papataxiarchis, and Michael Stewart

1999 Lilies of the Field: Marginal People Who Live for the Moment. Boulder, Colo.: Westview Press.

De Boeck, Filip

1998 "Domesticating Diamonds and Dollars: Identity, Expenditure, and Sharing in Southwestern Zaire (1984-1997).” Development and Change 29, no. 4: 777-810.

Dua, Jatin https://doi.org/10.1111/1467-7660.00099.

2019 Captured at Sea: Piracy and Protection in the Indian Ocean. Oakland: University of California Press. 
Galemba, Rebecca B.

2012 “'Corn is food, not contraband': The Right to 'Free Trade' at the Mexico-Guatemala Border.” American Ethnologist 39, no. 4: 716-34. https://doi.org/10.1111/j.15481425.2012.01391.x.

Guyer, Jane I.

2004 Marginal Gains: Monetary Transactions in Atlantic Africa. Chicago: University of Chicago Press.

2016 Legacies, Logics, Logistics: Essays in the Anthropology of the Platform Economy. Chicago: University of Chicago Press.

Heald, Suzette

1989 Controlling Anger: The Sociology of Gisu Violence. Oxford: James Currey.

1999 Manhood and Morality: Sex, Violence, and Ritual in Gisu Society. London: Routledge.

Keane, Webb

2008 "Market, Materiality and Moral Metalanguage." Anthropological Theory 8, no. 1: 27-42. https://doi.org/10.1177\%2F1463499607087493.

Kopytoff, Igor

1989 The African Frontier: The Reproduction of Traditional African Societies. Bloomington: Indiana University Press.

Kusimba, Sibel

2018 "Money, Mobile Money and Rituals in Western Kenya: The Contingency Fund and the Thirteenth Cow." African Studies Review 61, no. 2: 158-82. https://doi.

la Fontaine, Jean org/10.1017/asr.2017.145.

Lynch, Gabrielle

2011 I Say to You: Ethnic Politics and the Kalenjin in Kenya. Chicago: University of Chicago Press.

MacArthur, Julie

2016 Cartography and the Political Imagination: Mapping Community in Colonial Kenya. Athens: Ohio University Press.

MacKenzie, Donald

2003 "Long-Term Capital Management and the Sociology of Arbitrage." Economy and Society 32, no. 3: 349-80. https://doi.org/10.1080/03085140303130.

Maurer, Bill

2006 "The Anthropology of Money." Annual Review of Anthropology 35: 15-36. https://

Mbembe, Achille doi.org/10.1146/annurev.anthro.35.081705.123127.

2001 On the Postcolony. Berkeley: University of California Press.

McGovern, Mike

2018 A Socialist Peace? Explaining the Absence of War in an African Country. Chicago: University of Chicago Press.

Meiu, George Paul

2017 Ethno-Erotic Economies: Sexuality, Money, and Belonging in Kenya. Chicago: University of Chicago Press.

Miyazaki, Hirokazu

2007 "Between Arbitrage and Speculation: An Economy of Belief and Doubt." Economy and Society 36, no. 3: 396-415. https://doi.org/10.1080/03085140701428365.

2013 Arbitraging Japan: Dreams of Capitalism at the End of Finance. Berkeley: University of California Press.

Nakileza, Bob

2007 “A True Story of Coffees Magendo through Mount Elgon (Uganda)." Etudes Rurales 180: 131-36. https://doi.org/10.4000/etudesrurales.8538.

Newell, Sasha

2019 "Ethnography in a Shell Game: Turtles All the Way Down in Abidjan." Cultural Anthropology 34, no. 3: 299-327. https://doi.org/10.14506/ca34.3.01. 
Nyamnjoh, Francis B.

2017 "Incompleteness: Frontier Africa and the Currency of Conviviality." Journal of Asian and African Studies 52, no. 3: 253-70. https://doi.org/10.

Ocobock, Paul 1177\%2F0021909615580867.

2017 An Uncertain Age: The Politics of Manhood in Kenya. Athens: Ohio University Press.

Oka, Rahul, and Ian Kuijt

2014 "Introducing an Inquiry into the Social Economies of Greed and Excess." Economic Anthropology 1, no. 1: 1-16. https://doi.org/10.1002/sea2.12000.

Ong, Aihwa

2006 Neoliberalism as Exception: Mutations in Citizenship and Sovereignty. Durham, N.C.: Duke University Press.

Parry, Jonathan, and Maurice Bloch

1989 Money and the Morality of Exchange. Cambridge: Cambridge University Press.

Peterson, Derek R., and Edgar C. Taylor

2013 "Rethinking the State in Idi Amin's Uganda: The Politics of Exhortation.” Journal of Eastern African Studies 7, no. 1: 58-82. https://doi.org/10.1080/17531055.2012. 755314.

Peterson, Kristin

2014 Speculative Markets: Drug Circuits and Derivative Life in Nigeria. Durham, N.C.: Duke University Press.

Roitman, Janet

2004 Fiscal Disobedience: An Anthropology of Economic Regulation in Central Africa. Princeton, N.J.: Princeton University Press.

Shipton, Parker

1989 Bitter Money: Cultural Economy and Some African Meanings of Forbidden Commodities. Washington, D.C.: American Anthropological Association.

2007 The Nature of Entrustment: Intimacy, Exchange, and the Sacred in Africa. New Haven, Conn.: Yale University Press.

van Schendel, Willem

2005 "Spaces of Engagement: How Borderlands, Illegal Flows, and Territorial States Interlock." In Illicit Flows and Criminal Things: States, Borders, and the Other Side of Globalization, edited by Willem van Schendel and Itty Abraham, 38-68. Bloomington: Indiana University Press.

van Schendel, Willem, and Itty Abraham

2005 Illicit Flows and Criminal Things: States, Borders, and the Other Side of Globalization. Bloomington: Indiana University Press.

Wagner, Günter

1949 The Bantu of North Kavirondo: Volume I. London: Oxford University Press.

1956 The Bantu of North Kavirondo, Volume II: Economic Life. London: Oxford University Press.

Walsh, Andrew

2003 “'Hot Money' and Daring Consumption in a Northern Malagasy SapphireMining Town." American Ethnologist 30, no. 2: 290-305. https://doi.org/10.1525/ ae.2003.30.2.290.

Weiss, Brad

1993 “Buying her grave': Money, Movement and Aids in North-West Tanzania." Africa: Journal of the International African Institute 63, no. 1: 19-35. https://doi. org/10.2307/1161296.

1996 The Making and Unmaking of the Haya Lived World: Consumption, Commoditization, and Everyday Practice. Durham, N.C.: Duke University Press.

2003 Sacred Trees, Bitter Harvests: Globalizing Coffee in Northwest Tanzania. Westport, Conn.: Heinemann. 
Wekesa, Peter Wafula

2010 "Magendo and Survivalism: Babukusu-Bagisu Relations and Economic Ingenuity on the Kenya-Uganda Border 1962-1980." In Borders and Borderlands as Resources in the Horn of Africa, edited by Dereje Feyissa and Markus Virgil Höhne, 151-68. Suffolk: Boydell and Brewer.

Wilk, Richard

2014 "Poverty and Excess in Binge Economies." Economic Anthropology 1, no. 1: 66-79.

Willis, Justin https://doi.org/10.1002/sea2.12004.

2002 Potent Brews: Social History of Alcohol in East Africa 1850-1999. Athens: Ohio University Press.

Yeh, Rihan

2017 "Visas, Jokes, and Contraband: Citizenship and Sovereignty at the Mexico-U.S. Border." Comparative Studies in Society and History 59, no. 1: 154-82. https://doi.

Znoj, Heinzpeter org/10.1017/S0010417516000566.

1998 "Hot Money and War Debts: Transactional Regimes in Southwestern Sumatra." Comparative Studies in Society and History 40, no. 2: 193-222. https://doi.org/ 10.1017/S0010417598001066. 